\title{
Application of Flipped Classroom and Micro Class Teaching in English Reading and Writing Course in Independent Colleges
}

\author{
Wenting Zhang \\ Dianchi College of Yunnan University, Kunming, 650228
}

Keywords: Flipped Classroom, college English, reading and writing course, teaching application, autonomous learning, independent colleges

\begin{abstract}
With the deepening of new curriculum reform, English classroom teaching mode in colleges is no longer stuck to the traditional instillation method. Modern multimedia teaching mode such as Micro Class has entered college classroom. Modern teaching idea such as Flipped Classroom is more suitable for college students who have stronger autonomous learning ability, which will effectively promote the reform and optimization of college English curriculum. Starting with independent colleges, this paper analyzes the present situation and existing problems of English reading and writing course, and then probes into advantages and practical measures of Flipped Classroom and Micro Class in college English classroom.
\end{abstract}

\section{Introduction}

With the acceleration of economic globalization and the advancement of new curriculum reform, higher English education has gradually changed from the cultivation of basic knowledge and skills training to the fostering of English application ability and cross-cultural communication ability. At the same time, teaching level has been on the rise. However, college students still have low interest as well as efficiency in English classroom learning. This is a concrete manifestation of a lack of classroom teaching methods. While, the emergence of Micro Class and Flipped Classroom provides a new way to change the present situation of college English reading and writing course, which will promote the quality and efficiency of college English teaching to a higher level.

\section{Independent Colleges}

Independent colleges are also called "secondary colleges", most of which are run by private sectors, and only a few are run publicly or jointly. Independent colleges in most provinces and cities enroll the third batch of undergraduates, excluding the second and third emerged batch and only a very small number enroll the first or second one. Majors of most independent college are chosen from more popular and stronger ones in their alma maters. If alma maters are more famous with good teaching faculty, then the faculty and majors of independent colleges will be better too. But on the whole, they will not be as good as their alma maters. At present, to answer the call of the National Education Department, most independent colleges have begun to leave their alma maters to become private universities. This has opened the way for the development of independent colleges themselves, but also affected the level of their faculty as well as teaching quality and efficiency.

\section{College English Reading and Writing Course}

With the deepening of economic globalization, China has gradually participated in the international market and become an important economy in the global economy, attracting more and more international eyes. In recent years, increasing foreigners have appeared in our inland cities and second and third-tier cities. Our country has hosted world-class summit forums and conferences many times which is the most remarkable manifestation of our in-depth exchanges with the world. In this environment, demands of the society for the quality of English teaching in colleges and 
universities are gradually increasing, especially for students' ability to use English and cross-cultural communication ability. Under the premise of increasing market demands, there are still many problems in the process of college English reading and writing education.

As for students who have entered higher education stage, except for a few who are more interested in English and have stronger ability, most are indifferent to English learning, similarly to mathematics. Some students, because of their passion for English and American series as well as foreign stars, pay more attention to the study of words and phrases, devoting more energy to the study of oral speaking and listening. However, they have low interest in the culture behind English language, and have great difficulty in reading English articles, watching hard English plays and English writing. Therefore, teachers need pay more energy in class to arouse their attention and interest, and then improve classroom teaching efficiency. However, English teaching in colleges is designed to focus on students' autonomous learning and teachers are supposed to pay less attention to their daily learning. Therefore, on one hand, students have low interest and on the other hand, teachers want students to learn independently. These two sides bring great difficulty to improve the efficiency of English classroom teaching.

College English teaching tends to take the form of large classes. Since there are many students in class, teachers' classroom interaction can only cover a few students, which makes the degree of classroom teaching participation and interaction poor. In colleges, teachers stress students' autonomous learning and are only impressed by a small number of students who are highly motivated or mischievous, putting a low degree of restraint on most students' listening state, which leads to students' lack of concentration in class, low enthusiasm for learning, and decreasing teaching and learning as a result.

Although teaching reform has been promoted from various aspects for many years, the traditional teaching mode has not completely disappeared in college English reading and writing course. In addition, exam-oriented education is not rare in English class before CET4 and CET6. The phenomenon that some students from non-English majors no longer have English course arrangement after CET4 and CET6 is a strong evidence of the existing of exam-oriented education. College teachers should stress students' autonomous learning ability, English application ability and cross-cultural communication ability, no longer too much attention to words, grammar and other basic knowledge, since such outdate teaching means is difficult to meet the needs of students.

\section{Advantages of Flipped Classroom and Micro Class Teaching in College English Reading and Writing Course}

Flipped classroom is a kind of teaching form that reverses the traditional classroom teaching mode, contents and time. It puts the study of basic stage of classroom teaching contents in pre-class preparation stage, and urges students to autonomously learn according to pre-class study task list arranged by teachers. In class, teachers are required to pay more attention to students' individualized education and ability improvement. This is a new and modern teaching method, which gives full play to the student-centered teaching idea and sets up classroom teaching on students' learning level. It is conducive to effectively improves the quality and efficiency of classroom teaching, cultivate the independent learning consciousness and ability of contemporary college students, and promote them to grasp classroom teaching contents and key points more deeply.

Micro class is one of the modern means which cuts teaching contents according to key points into short videos. This kind of teaching videos highlights the key and difficult points with an obvious theme, and can help students to learn the most effective knowledge within a short time. Micro Class gradually becomes an important teaching aid to help students improve the quality and efficiency of learning. Micro-class teaching has gradually become an important part of Flipped Classroom. Using micro-class to learn before class can effectively improve the effect of students' autonomous learning, give more prominence to their subjective status, and help them to better grasp the key teaching contents.

The cooperation of Flipped Classroom and Micro Class makes their advantages in college 
English class more obvious. They play an important role from students' self-learning to classroom teacher-student interaction, and from students' critical thinking to the cultivation of innovative thinking, guiding teachers to train lifelong learning talents.

The cooperation of Flipped Classroom and Micro Class teaching makes it easier for students to expand their autonomous learning with the assistance of network resources, and make use of abundant network resources to help students understand and digest key points more comprehensively and deeply. Under the scouring of massive Internet information, students are able to treat the same problem from many angles without being restricted by the contents and ideas of textbooks, which are conducive to opening up students' innovative and critical thinking, help them to better accept college English reading materials, and translate knowledge into writing better.

Flipped Classroom offers teachers more time and energy to interact with students in classroom teaching, supply them more opportunities to make use of teaching activities to communicate with students face to face, make them learn more about students' knowledge reserve and learning ability so as to arrange more accurate individualized reinforcement and improvement, solve more learning problems for students in class and effectively improve the quality and efficiency of students' classroom learning. Interaction makes the relationship between teachers and students close quickly, and students will have more confidence to seek help from teachers in terms of knowledge and growth, which is conducive to improving students' comprehensive ability.

\section{Application Measures of Flipped Classroom and Micro Class Teaching in College English Reading and Writing Course}

Traditional college English reading and writing teaching highly depends on teaching materials. Teaching activities and plans are carried out according to textbooks. However the contents of textbooks and ability of writers are limited. The extensible scope of same teaching contents far exceeds the extent to which the teaching materials can be accommodated, so even teachers cannot include all teaching materials. Limited teaching materials and teachers' ability greatly constrain the breadth and depth of students' learning, vision and thinking. The Flipped Classroom and Micro Class teaching put the basic contents learning to pre-class stage, which makes it more easily to expand the contents of textbooks, and provides the possibility for students to learn deeply. Teachers can also promote students' autonomous learning and in-depth learning by setting up learning task list and make the results of students' autonomous learning additional materials of classroom teaching. For example, during class group discussions, the exchange of different students' autonomous learning results can effectively enrich the classroom teaching contents and supplement teachers' unprepared part.

The task list of Flipped Classroom takes on the responsibility of designing and laying the groundwork for the classroom interactive environment. Teachers can urge students to study independently by setting up tasks in advance, and let them have a grasp of the key points of interaction in class. The process of preparing interactive contents in advance is to promote and supplement students' autonomous learning. In class, problems encountered by students in the process of self-study are firstly discussed in groups, so that students who do not find this problem have chances to think and discuss, and then have targeted communication and solution. This kind of classroom interaction makes students' main body status more prominent, and provides pertinence supplementary and enhancement according to students' question and insufficiency. Compared with the traditional teaching way, this kind of teaching has a higher quality and efficiency.

It is quite boring and difficult to learn a language alone. However, if cultural background derived from the language is added, it can help students understand and accept problems that they could not understand, improve their interest in English and make them learn English better. In Flipped Classroom and Micro Class teaching, teachers are capable of choosing to put key teaching knowledge in pre-class learning stage and the extension of cultural background in classroom teaching stage, so that students can better understand English knowledge in cultural environment. For example, students who grow up in the traditional teaching mode could not understand the meaning of the phrase "in coming out of my ears" at all. If students could understand some phrases 
encountered in English reading and watching English American TV series, they will fail to naturally apply those phrases. They will not only stumble in English reading and produce boring articles with low test scores, but also run into communication accidents in the future interaction with foreign friends. The phrase "coming out of my ears" means "abundant" and "rich", which equals to words like "plentiful", "well-off”, and "comfortable". "Coming out of my ears" is more in line with the current trend and habits of communication in English speaking countries. This kind of English knowledge points and cross-cultural communication effectively promote students' interest in English learning and cultural background learning. There are many foreigners on Webs doing similar micro class teaching. For example, @ An Long Cameron is an Australian, who has traveled around the world and done water sports. He was originally a lawyer, and is currently a bilingual host in Shanghai Oriental Media. His Micro Class videos can effectively link up the cultural differences between the East and the West interestingly. This kind of Micro Class greatly helps to improve the learning effects of students.

\section{Conclusion}

English is very important to college students under the current world situation and social development environment, and is the best way for students to learn all their life and communicate with other countries. Therefore, teaching quality of reading and writing course in college is directly related to students' learning, growing and communicating ability after entering the society. For this reason, college teachers should be familiar with them as soon as possible, adapt to modern teaching mode and methods such as Micro Class teaching and Flipped Class, combine them with college English reading and writing course, and enhance students' enthusiasm for English learning, improve the quality and efficiency of classroom teaching and learning, and provide communication skills guarantee for students to enter the society in the future.

\section{References}

[1] Gong Hongxia. Application Analysis of Flipped Classroom and Micro Class Teaching in College English Reading and Writing Course [J]. Overseas English, 2018 (06): 9-10.

[2] Wang Juan, Tao Yongsheng, Shen Juli, Ye Ji Yun, Qu Yan, Zhao Zhen. Application of PBL Teaching Method Combined with the Flipped Class in the Teaching of College English Reading and Writing Course [J]. Journal of Kunming Medical University, 2018, 39 (02): 128-133.

[3] Liu Hao. A Study of the Application of the Combination of English Grammar Teaching and College English Reading and Writing Course Based on Micro Class [J]. Journal of Hunan University of Science and Engineering, 2017, 38 (04): 121-123+126.

[4] Ma Hui, Zhai Xiaoli. Application of Flipped Classroom Teaching Mode in College English Reading and Writing Teaching [J]. Overseas English, 2016 (17): 23-24.

[5] Zhang Yanlei, Wu Xuan. Application of Flipped Classroom and Micro Teaching in College English Writing Class [J]. Overseas English, 2016 (15): 87-88.

[6] Yang Jing. Application of Flipped Classroom Based on Micro Class in College English Reading and Writing Teaching for Special Majors [J]. English Square, 2015 (12): 61-62. 